\title{
2nd Mexican Consensus of Endovenous Chemical Ablation (Scleorotherapy) 2018*
}

\section{Zweiter mexikanischer Konsensus zur endovenösen chemischen Ablation (Sklerotherapie) 2018}

Authors

F. Vega Rasgado, J. Ángel López Paredes, J. A. Serralde Gallegos, D. Bolaños Celaya, C. Ramírez Cadena, M. Alberto Cavazos Ortega, O. Lira Rodríguez, F. Rendón Elías, F. Contreras Cisneros, A. Lugo Ramírez, E. Jiménez Gorena

\section{Affiliations}

Academia Mexicana de Flebología y Linfología, Mexico City, 2018

Key words

Sclerotherapy, consensus, endovenous chemical ablation (ECA)

Schlüsselwörter

Sklerotherapie, Konsensus, endovenöse chemische Ablation (ECA)

received 03.04.2018

accepted 26.06.2018

\section{Bibliography}

DOI https://doi.org/10.1055/a-0894-9896

Online-Publikation: 22.05.2019

Phlebologie 2019; 48: 377-387

(c) Georg Thieme Verlag KG Stuttgart · New York ISSN 0939-978X

\section{Correspondence}

Dr. Fernando Vega Rasgado

Xocoyahualco \#78

Colonia Nueva Ixtacala

Tlalnepantla

Estado de México

C.P. 54160

México

E-Mail: imf_fer@hotmail.com

\section{ABSTRACT}

Background Sclerotherapy has been carried out since 1516 and is accepted and performed worldwide according to many references from books and journals. Mexican doctors participated in other consensuses in order to obtain various agreements, references, methods and procedures that are universally accepted to establish this document, including the European consensus of sclerotherapy 2003 and

* Collaborators: Dr. Hugo Cázares Baruch, Dr. Guillermo Uribe, Dra. Blanca Viviana Pastrana Escudero, Dr. Román Flores, Dr. Fernando Torres, Dr. Antonio Ramírez Cadena its last revision in 2006, the Clinical practice guidelines for prevention, diagnosis and treatment of chronic venous insufficiency in 2009 in México, the Argentine and Latin American consensus for sclerotherapy in 2012, European sclerotherapy guidelines in chronic venous diseases of 2013, and various literature sources as well. The first Mexican consensus on sclerotherapy published in January 2014 which was reviewed and updated in this document.

Objective Review and update the general bases of Endovenous Chemical Ablation (ECA) also known as Sclerotherapy, according to evidence-based medicine updating the previously published consensus.

Method General questions about Endovenous Chemical Ablation (ECA) were established concerning: indications, contraindications, types of sclerosing agents and the concentrations used, patient position, methods of application, way to prepare and preserve the sclerosants, necessary equipment, injection volumes, differents administration ways, compressive therapy and special comments. To answer these questions the existing literature and the topics in which the reports showed uniformity were consulted. A panel of experts was constituted who provided their personal experience, the answers were formulated in the form of clinical guidelines or general recommendations to provide concrete answers to the specific questions, in some issues we include possible accepted variations.

\section{ZUSAMMENFASSUNG}

Hintergrund Die Sklerotherapie wird seit 1516 angewendet und ist laut Veröffentlichungen in Lehrbüchern und Zeitschriften ein weltweit akzeptiertes und durchgeführtes Verfahren zur Therapie von Varizen.

Die verschiedenen Meinungen zu den allgemein akzeptierten und etablierten Methoden und Abläufen konnten mexikanische Ärzte auf Konsensus Konferenzen, wie dem „European consensus of sclerotherapy “ 2003 und 2006, der „Clinical practice guidelines for prevention, diagnosis and treatment of chronic venous insufficiency“ 2009, der „Argentine and Latin American consensus for sclerotherapy“ 2012, der „European sclerotherapy guidelines in chronic venous diseases, 2013“ und durch publizierter Literatur sammeln und in den 2. mexikanischen Konsensus einfließen lassen. 
Der erste mexikanische Sklerotherapie-Konsensus wurde im Januar 2014 publiziert und wurde nun überarbeitet und aktualisiert.

Zielsetzung Überarbeitung und Aktualisierung des 1. mexikanischen Konsensus zur endovenösen chemischen Ablation (ECA), auch bekannt als Sklerotherapie, gemäß der Regeln der Evidenz-basierten Medizin.

Methode Allgemeine Fragen und Themen zur endovenösen chemischen Ablation (ECA) wurden bearbeitet. Im Einzelnen: Indikationen, Kontraindikationen, Sklerosierungsmittel und zu verwendete Konzentrationen, Position des Patienten, Applikationsmethoden, Art und Weise der Zubereitung und
Erhalt des Sklerosierungsmittels, notwendiges Equipment, Injektionsvolumen, unterschiedliche Zugangswege, Kompressionstherapie und speziellen Anmerkungen. Um diese Fragen zu beantworten, wurden die existierende Literatur und Berichte mit einheitlicher Meinung zu einem Thema herangezogen. Eine Gruppe von Experten beantwortete Fragen auf Grundlage ihrer persönlichen Erfahrung. Die Antworten wurden in Form von klinischen Leitlinien oder allgemeinen Empfehlungen formuliert, so dass konkrete Antworten auf spezifische Fragen gegeben werden konnten. In manchen Fällen wurden mehrere mögliche Variationen akzeptiert.

\section{CONSENSUS TOPICS}

\section{Overview}

1.1 Prerequisites

1.2 Definition of Endovenous Chemical Ablation (Sclerotherapy)

1.3 Physical forms of sclerosing application

1.4 Indications

1.5 Contraindications

1.5.1 Absolute

1.5.2 Relatives

1.6 Sclerosing agents

1.7 Concentrations and dose of Sclerosing agents

1.8 Volumes of Sclerosants (liquid and foam)

\section{Material and Equipment}

2.1 General material

2.2 Syringes and Catheters

2.3 Needles

2.4 Medical Devices

2.5 Compression devices

\section{About the Patients}

3.1 Position of the Patient during the ECA

3.1 Post-ECA Compression

\section{Aditional Comments}

\section{CONCEPTUAL FRAMEWORK}

Many worldwide attempts have been made to have standardized criteria to perform Endovenous Chemical Ablation (ECA), the concept of our consensus will be reflected in two aspects:

- Consensus: Methods and conditions ac-cepted unanimously

- Variations: Methods and conditions that can be changed according to experience of the panel in relation to the general consensus.

This concepts will allow us to establish general guidelines to perform the ECA and at the same time, variations accepted in our country according to medical expertise and the worldwide bibliography.

\section{GLOSSARY}

Sclerosing Agent (SA): Chemical that causes damage to the endothelium and the venous wall.

Polidocanol (POL): Aethoxylerol (Lauromacrogol 400), chemical substance widely known as sclerosing worldwide. (Formula)

Tetradecyl Sodium Sulfate (TDS): Sclerosing substance for main use in the United States and Europe. (Formula) Glycerin (Gl): Sclerosing substance (glycerol) of oily type. (Formula)

Chromed glycerin (GC): An oily-type sclerosing substance with a Chrome group attached to the glycerol molecule. Foam (FOAM): Physical form of preparing the sclerosant in different ways (bubbles of different diameter and with different gas).

Tessari Method (TM): Method described by Lorenzo Tessari for the preparation of sclerosant foam using a three-way stopcock.

Room Air (RA): The air commonly used to prepare sclerosant foam. 
Oxygen (O2): Oxidizing gas in its pure form used to prepare sclerosing foam.

Carbon Dioxide (CO2): Physiological gas used to prepare sclerosant foam.

Pulmonary Embolism (PE): Thrombosis of any branch of the pulmonary artery usually caused by thrombus from a distance.

Deep Venous Thrombosis (DVT): Thrombosis in the deep venous system.

Superficial Venous Thrombosis (SVT): Thrombosis in the superficial venous system.

Great Saphenous Vein (GSV): Vein that originates in the inner side of the ankle and empties into the groin in the Sapheno-femoral junction (Vein Safena interna, or Safena long). Small Saphenous Vein (SSV): A vein that originates on the external surface of the ankle and usually ends in the saphenous-popliteal junction in the popliteal fossa.

Perforating Vein (PV): Veins that communicates between the superficial and deep system by perforating one or more muscular fasciae.

Doppler Color Ultrasound (DCU): Non-invasive diagnostic method for the anatomical and functional evaluation of the venous system.

Transillumination (TI): Method by which light is applied through the skin to identify veins that are not apparent to the naked eye.

Polarized Light (PL): Method to visualize dermal venous branches.

\section{Consensus}

\section{Generalities}

\subsection{Prerequisites}

I. Informed Consent

II. Medical history (including photos and scheme) where the diagnosis is as specific as possible, including the CEAP system.

III. Performed by medical personnel who documented Phlebology training.

IV. Having the necessary equipment

V. Having the red team gadget (NOM-178-SSA1-1998 Medical Office).

VI. To be sure the procedure is specifically indicated with each patient.

VII. Appropiate environmental conditions.

\subsection{Definition of Endovenous Chemical Ablation (Sclerotherapy)}

ECA is a treatment method for venous pathology consisting of the intravenous administration of a chemical substance which damages the venous endothelium producing the subsequent inflammatory changes, triggering the formation of an expected and controlled thrombus in a selected venous segment with its subsequent defunctionalization.

\subsubsection{Forms of Use of Sclerosing Agents}

We have two physical forms to apply the sclerosing agents:

a Liquid

b Foam

The Foam is prepared by Tessari method using a 3-way tap and two syringes using the following gases:

- Room Air (approximately $70 \%$ of Nitrogen)

- $\mathrm{CO}_{2}-\mathrm{O}_{2}$ mixture

- $\mathrm{O}_{2}$ (pure oxygen)

For this preparation, the dilution proposed by Dr. Tessari is used: 1 part sclerosing liquid and 4 parts gas.

Other methods can be considered as „Air Block“. The double syringe system is not yet available in Mexico, however there are other similar devices that can be achieved.

\subsection{Indications of the ECA (Endovenous Chemical Ablation)}

ECA can be applied in dysfunctional or varicose veins, angiodysplasia or in secondary angiogenesis problems.

Some books and papers talk about the Indications of this procedure, which are the following:

a Saphenous vessels and their tributaries

b Secondary varices: Residual or Recurrent

c Other kind of varicose veins: Post-traumatic, Gestational, Post-thrombotic, post-surgical etc.

d Telangiectasias

e Reticular Veins

$f$ Perforating veins

g Vulvar varicosis and pelvic congestion syndrome

h Hemorrhoidal Disease (I-II grades)

i Some Malformations and Vascular Diseases

Variant: ECA, can be used in selected cases of post-thrombotic syndrome and other body areas.

\subsection{Contraindications}

\subsubsection{Absolute}

a Known allergy to sclerosant

b Patient with severe acute diseases

c Chronic arterial insufficiency, with lower ankle-brachial index 0.6 , corresponding to arterial occlusion grade III-IV Fontaine scale.

d Acute or subacute venous thrombosis (less than 6 months)

e Acute febrile state

$f$ Unbalanced/uncontrolled systemic diseases

$\mathrm{g}$ Acute eczema

h Infectious dermatosis

i Pregnancy, use only in an emergency

j Immobilized patients 
- Tab. 1 Sclerosing, Dosing and Recommended Puncture Volumes according to the Type of Vein to be treated (Depending on the diameter).

\begin{tabular}{|c|c|c|c|c|c|c|}
\hline \multirow[b]{2}{*}{ TYPE OF VEIN } & \multicolumn{3}{|c|}{ POLIDOCANOL (Lauromacrogol 400) } & \multicolumn{3}{|c|}{ TETRADECYL SODIUM SULPHATE } \\
\hline & $\begin{array}{l}\text { Liquid } \\
\text { Concentration }\end{array}$ & $\begin{array}{l}\text { FOAM } \\
\text { Concentration }\end{array}$ & $\begin{array}{l}\text { Maximum } \\
\text { Volume }\end{array}$ & $\begin{array}{l}\text { Liquid } \\
\text { Concentration }\end{array}$ & $\begin{array}{l}\text { FOAM } \\
\text { Concentration }\end{array}$ & $\begin{array}{l}\text { Maximum } \\
\text { Volume }\end{array}$ \\
\hline Great Saphenous Vein \&SF] & & $3 \%$ & $10 c c$ & & $1.5 \%$ & $6 c c$ \\
\hline Small Saphenous Vein \&SPJ & & $1-3 \%$ & $5 c c$ & & $1-1.5 \%$ & $4 \mathrm{cc}$ \\
\hline Tributary Veins & $1-3 \%$ & $1-3 \%$ & $8 \mathrm{cc}$ & $1 \%$ & $0.75-1.5 \%$ & $3 c c$ \\
\hline Perforating Veins & $1-3 \%$ & $1-3 \%$ & $3 \mathrm{cc}$ & & $0.5-1 \%$ & $1 \subset c$ \\
\hline Reticular Veins & $0.5-1 \%$ & $0.25-0.5 \%$ & $3 \Subset c$ & $0.3 \%$ & $0.1-0.15 \%$ & $0.5 c c$ \\
\hline Telangiectases & $0.25-0.5 \%$ & $0.1-0.25 \%$ & $3 \mathrm{cc}$ & $0.1-0.15 \%$ & $0.1 \%$ & $0.5 c c$ \\
\hline
\end{tabular}

-Tab. 2 Sclerosing Agents Used in Small-caliber Veins.

\begin{tabular}{|l|l|l|l|l|l|}
\hline & CHROMED & GLYCERIN & DEXTROSE & GLYCERIN \\
\hline TYPE OF VEIN & $\begin{array}{l}\text { Liquid } \\
\text { Concentration }\end{array}$ & $\begin{array}{l}\text { Maximum } \\
\text { Volume }\end{array}$ & $\begin{array}{l}\text { Liquid } \\
\text { Concentration }\end{array}$ & $\begin{array}{l}\text { Maximum } \\
\text { Volume }\end{array}$ & $\begin{array}{l}\text { Liquid } \\
\text { Concentration }\end{array}$ \\
\hline Reticular Veins & $25 \%$ & $3 c c$ & $50 \%$ & $24 \%$ & $5 c c$ \\
\hline Telangiectases & $25 \%$ & $2 c c$ & $25 \%$ & $5 c c$ & $24 \%$ \\
\hline
\end{tabular}

\subsubsection{Relatives}

- Bedridden or sedentary, as well as with neurological motor damage

- Thrombophilia

- Multifactorial thrombosis:

- Hormone therapy

- Contraceptives

- Significant Obesity

- Smoking

- Severe COPD (Chronic Obstructive Pulmonary disease)

- Foramen Oval Permeable (in case of using foams)

- Phlebedema grade IV and Lymphedema grade IV

- Leucodermatosclerosis not modifiable by compression

- Anticoagulant therapy

- Breastfeeding

- Lactation

\subsection{Sclerosing Agents}

There are a wide variety of Sclerosing Agents, however, the most used depending on their availability are:

- Polidocanol (Lauromacrogol)

- Tetradecyl Sodium Sulphate

- Glycerin

- Chromic Glycerin

- Hypertonic Solutions (Dextrose and Saline)

In Mexico, the only sclerosing agent authorized by the sanitary authorities is “Aethoxylerol ${ }^{\circledR}$ " (Polidocanol, Lauromacrogol 400).

Sclerosants: They are administered in different physical states and concentrations for which; some equipment, additives, gases
- Tab. 3 Recommended Needle Calibers and Syringes.

\begin{tabular}{|l|l|l|}
\hline TYPE OF VEINS & Needle - Catheter & Syringe \\
\hline $\begin{array}{l}\text { Telangiectases, Spider and } \\
\text { Reticular Veins } \\
\text { Veins with diameter }>4 \mathrm{~mm}\end{array}$ & $27-31 \mathrm{G}$ & $0.5-3 \mathrm{ml}$ \\
\hline
\end{tabular}

or diluents widely cited in the world literature are used, the panel endorses the following:

Dosage: The use of liquid form or foam and the suggest doses and volumes are described in $\downarrow$ Tab. 1 and $\triangleright$ Tab. 2 .

Gases: Usually room air is used but pure Oxygen, $\mathrm{CO}_{2}$, and $\mathrm{O}_{2}$ $\mathrm{CO}_{2}$ mixtures are also available, as described in different Works.

Diluents: The most used are: Distilled Water, Bidestilated Water, $0.9 \%$ Saline Solution, Lactate Ringer's Solution and 5 \% Glucose. Depending on the availability of the diluent and personal experience.

\subsection{Concentrations and Maximum Dose of Sclerosing Agents}

The following doses are recommended in relation to the type of vein to be treated, which will be directly related to their diameters ( $\triangleright$ Tab. 1 and $\triangleright$ Tab. 2 ).

Polidocanol (Lauromacrogol 400): It can be supplied in concentrations ranging from $0.25 \%$ to $3 \%$. Currently in our country it is available in ampules of to $0.5 \%, 1 \%, 2 \%$ and $3 \%$. Maximum dose of Polidocanol: $2 \mathrm{mg} / \mathrm{Kg}$ of bodyweight. 
Tetradecyl Sodium Sulfate: The literature suggests the use of concentrations ranging from $0.1 \%$ to $1.5 \%$. Maximum Tetradecyl Sodium Sulfate Dose: $4 \mathrm{ml} 3$ \% (not available in México)

\subsection{Volumes of Sclerosants (Liquid and Foam)}

There are several works on the volumes of foam that should be administered to each patient, it is important to note that the global variation is very wide, ranging from 1 to $60 \mathrm{ml}$; which is due to the concentration, gas used for foam, time of administration, number and type of veins to be treated and the personal experience of the physician.

It is recommended to use a maximum volume each session of $10 \mathrm{cc}$ of the sclerosing agent, the average volumen suggested by the panel is $5 c c$ in both liquid or foam form ( $>$ Tab. 1 and $>$ Tab. 2).

Remarks: This consensus DOES NOT limit the use of different concentrations or volumes, since, in differents part of the country, institution or personal experience, they can be varied according to optimizing the results for the patient.

Recommendations after Endovenous Chemical Ablation (Sclerotherapy):

a Elevation of the treated limb of $10-15^{\circ}$ by 5 to $10 \mathrm{~min}$. with flexion-extension exercise of the ankle.

b Put on a Elastocompression system

c Immediate mobilization after 5-10 minutes (see above)

d Consider that adverse effects may occur

e Keep in touch with the patient.

$f$ Percutaneous thrombectomy by puncture or aspiration in the next 10 days.

\section{Material and Equipement}

2.1 Material

- Cotton

- Alcohol

- Disposable gloves

- Adhesive Tapes

- Gauzes

- Antiseptic solutions

- Physiological Solution $100 \mathrm{ml}$ and $250 \mathrm{ml}$

- Pads with Alcohol (Wipes)

- Work table

- Scissors

- Measuring tape

- Marker (Surgical and Indelible)

- 3 way keys

- Hypodermic needles

- Blood pressure cuff

- Stethoscope

- Lamps

- Elevators for the limb

\subsection{Syringes and Catheters}

Disposable syringes of: $0.5,1,3,5$ and $10 \mathrm{cc}$.

Catheters (short or long) with different needle gauges.

Other devices of similar calibers (punzocats, butterflies, etc.)

10 and $20 \mathrm{cc}$ syringes are recommended only for dilutions ( Tab. 3).

\subsection{Needles}

The following needle size and syringes are recommended to puncture the veins according their diameter. ( $\triangleright$ Tab. 3). When injecting Foam through needles with gauge greater than $27 \mathrm{G}$, the bubbles are destroyed and liquid is mostly injected, therefore no needles larger than $27 \mathrm{G}$ are recommended for foam injection into large diameter veins.

\subsection{Medical Devices}

- Venous Transilluminator: The panel agreed that transillumination equipment is mandatory in the ECA procedure.

- Polarized Light and Magnifying Glasses: Polarized light eliminates reflections due to the refraction of light in the dermis, which allows us to observe with greater precision Telangiectasias and small caliber vessels, the magnifying glasses allow to observe not perceptible veins under conventional conditions.

- Vein Visualizer in Real Time: System that emits a near infrared light, which when absorbed by the blood, produce the reflection of it and project a digital image of the veins on the skin.

- Linear Doppler or Hand Doppler: It is essential to have Linear or hand Doppler equipment for diagnosis and verification of the arterial and venous points and verify the ankle-brachial index (ABI).

- Ultrasound Doppler Color: The Color Doppler equipment is accepted worldwide as the ideal device for the diagnosis of venous disease, being also very useful to perform punctures of the vascular system and essential to ultrasound guided ablation and sclerosis treatments.

- Oxygen Tank: Medical Oxygen can be used through nasal tips or to prepare foam.

- CO2 (Carbon Dioxide) Tank: Medical use gas which is used in a non-routine way to prepare the foam of the sclerosing agent.

- Oximeter: Useful for testing arterial saturation of the $\mathrm{O} 2$ after bandages.

- Photographic camera: For medical records and as clinical evidences.

- Computer

Variant of Equipment and Additional Devices:

- Glucometer

- Needle Extenders

- Podium for Exploration

- Pletismograph

\subsection{Material for Compression}

The Elastocompression system is considered as indispensable strategy after the treatment of ECA, which can be done with the following materials:

- Elastic bandages of 10 and $15 \mathrm{~cm}$. (High, medium and low compression).

- Compression socks higher than $25 \mathrm{mmHg}$.

For compression stockings, it can be used below the knee, thigh or pantyhose, depending on the preference and sclerosed area. 


\section{About the Patients}

\subsection{Position of the Patient during the ECA}

It is preferred to perform the ECA with the patient in lying position, which will avoid the presence of accidents caused by lipothymia or adverse reaction to the sclerosing agent, in addition to offering greater comfort.

In sometimes the evident varicosities in standing position disappear with the lying postion, then by this:

a Proof if the veins can be located with Transillumination device.

b Mark the insufficient veins with the patient standing before chemical ablation in decubitus.

c Sit the patient on the examination table with the leg hanging and treat the insufficient veins in this position, immediately afterwards place the patient in lying position.

\subsection{Compression After- ECA}

The usefulness of compressive therapy is described in many works auxiliary to prevent reflux, promote the venous upflow, decrease venous stasis, edema and pain, in addition to improve the lymphatic function, the microcirculation and promote the healing of venous ulcers.

The placement of a venous compression system after performing ECA (sclerotherapy) is unanimous. The use of bearings, cotton or other direct compression system on the sclerosed veins is convenient but not a generalized practice.

\section{Additional Observations}

1. Prior to the ECA procedure it is suggested: Avoid the tight clothing, do not apply creams, avoid exposure to sunlight and laser hair removal sessions (2 weeks before).

2. Adverse, Collateral, Secondary Effects and Complications of ECA (Sclerotherapy):

Injection of a sclerosant can produce in some cases: cardiac abnormalities, cough and respiratory disorders, vomiting, visual disturbances, metallic taste, fever, back pain or headache, but it can also produce local reactions such as phlebitis or even ulcers by extravasation.

Like any other substance it can lead to allergic reactions such as rash, urticaria or even anaphylaxis reactions.

The adverse effects of ECA are mainly:

- Ecchymosis

- Local pain when applying the sclerosing agent

- Intense and continuous pain in the treated site

- Superficial Phlebitis and thrombophlebitis

- Dermatitis, itching, non-allergic erythema

- Local necrosis and ulcers due to extravasation

- Cough and dyspnea

- Nausea and vomiting

- Neurological injuries, Neuromas, Neuropraxia or Neuritis

- Deep Venous Thrombosis

- Neovascularization post sclerotherapy (Matting)

- Lipothymia and Disorders in the gait

- Headache, Migraine and Dizziness

- Paresthesias, Aphasia, Ataxia and Hemiparesis

- Transient Loss of Consciousness and Confusion
- Metallic Flavor and Hypoesthesia and/or Oral Dysesthesia (Orofacial)

- Scotoma and Transient disturbance of the vision

- Alteration into the General Condition (Fever, Asthenia, Adynamia)

- Hypertrichosis

Complications of ECA (sclerotherapy) described in the literature worldwide:

- TIA

- Stroke

- Anaphylactic Shock and Angioedema

- Tachycardia, Arrhythmias and Cardio Respiratory Arrest

- Tako-Tsubo Syndrome and other cardiac complications

- Venous Thromboembolic Disease (Pulmonary Embolism)

- Instability of blood pressure (Hypotension-Hypertension)

- Ischemia in the limbs by intra arterial application of the sclerosant

- Vasovagal Syncope

- Angina Pectoris

- Vasculitis

4. Evaluation and therapeutic continuity is recommended from 1 to 4 weeks.

5. Medications and Local Measures after ECA:

Physicians use drugs after Endovenous Chemical Ablation in the following proportions:

- Anti-phlebitic Medications: $10 \%$

- Non-Pharmacological Agents with Anti-phlebitic Effect (naturist): $90 \%$

- Topical gels: $10 \%$

- Analgesics and Oral Anti-inflammatories: 10\%

- Local Cold: $15 \%$

6. It is not advised to apply sclerosants via the perivascular route, although this is described as an option.

7. Post-sclerotherapy thrombectomy is ussually required by Percutaneous puncture or Aspiratiion within the first 10 days after the treatment and at any time that is necessary.

8. In México, it is mandatory to collect the following documents, before conducting sessions of Endovenous Chemical Ablation (Sclerotherapy):

a Complete Medical Record (Printed or Electronic)

b Medical history according to NOM-004-SSA3-2012 of the Medical Record

c Phlebological Background Format

d Informed Consent to treatment

e Specific Registry of each medical and therapeutic session

$f$ Authorization to obtain sensitive data and to take photographs

Annexes

A) Medical history

Phlebological record Format 
B) Informed Consent

Authorization for the procedure, collect sensitive data and take pictures.

\section{Comment}

This 2. Mexican consensus on sclerotherapy is valid for Mexican doctors only. In Germany the European guidelines for sclerotherapy in chronic venous disorders are valid (Rabe et al. Phlebology 2014; 29(6): 338-354).

\section{Conflicts of interest}

The authors declare that they have no conflicts of interest.

\section{References}

[1] Alos J, Carreno P, Lopez JA et al. Efficacy and safety of sclerotherapy using polidocanol foam: a controlled clinical trial. Eur J Vasc Endovasc Surg 2006; 31: 101-107

[2] Beckitt T, Elstone A, Ashley S. Air versus physiological gas for ultrasound guided foam sclerotherapy treatment of varicose veins. Eur J Vasc Endovasc Surg 2011; 42: 115-119

[3] Bergan JJ, Weiss RA, Goldman MP. Extensive tissue necrosis following high concentration sclerotherapy for varicose veins. Dermatol Surg 2000; 26: 535-542

[4] Bidwai A, Beresford T, Dialynas M et al. Balloon control of the saphenofemoral junction during foam sclerotherapy: proposed innovation. J Vasc Surg 2007; 46: 145-147

[5] Bihari I, Magyar E. Reasons for ulceration after injection treatment of telangiectasia. Dermatol Surg 2001; 27: 133-136

[6] Bihari I, Tasnadi G, Bihari P. Importance of subfascial collaterals in deep-vein malformations. Dermatol Surg 2003; 29: 146-149

[7] Blaise S, Bosson JL, Diamand JM. Ultrasoundguided sclerotherapy of the great saphenous vein with $1 \%$ vs. $3 \%$ polidocanol foam: a multicentre doubleblind randomised trial with 3-year follow-up. Eur J Vasc Endovasc Surg 2010; 39: 779-786

[8] Blaise S, Charavin-Cocuzza M, Riom H et al. Treatment of low-flow vascular malformations by ultrasoundguided sclerotherapy with polidocanol foam: 24 cases and literature review. Eur J Vasc Endovasc Surg 2011; 41: 412-417

[9] Blomgren L, Johansson G, Bergquist D. Randomized clinical trial of routine preoperative duplex imaging before varicose vein surgery. $\mathrm{Br}$ J Surg 2005; 92: 688-694

[10] Bradbury AW, Bate G, Pang K et al. Ultrasound-guided foam sclerotherapy is a safe and clinically effective treatment for superficial venous reflux. J Vasc Surg 2010; 52: 939-945

[11] Breu FX, Guggenbichler S, Wollmann JC. 2nd European Consensus Meeting on Foam Sclerotherapy, 28-30 April 2006, Tegernsee, Germany. Vasa 2008; 37(Suppl. 71): 1-32

[12] Brodersen JP. Catheter-assisted vein sclerotherapy: a new approach for sclerotherapy of the greater saphenous vein with a double-lumen balloon catheter. Dermatol Surg 2007; 33: 469-475

[13] Brunken A, Rabe E, Pannier F. Changes in venous function after foam sclerotherapy of varicose veins. Phlebology 2009; 24: 145-150
[14] Bullens-Goessens YIJM, Mentink LF et al. Ultrasoundguided sclerotherapy of the insufficient short saphenous vein. Phlebologie Germany 2004; 33: 89-91

[15] Busch RG, Derrick M, Manjoney D. Major neurological events following foam sclerotherapy. Phlebology 2008; 23: 189-192

[16] C B Asbjornsen et al. Middle cerebral air embolism after foam sclerotherapy Phlebology 2012;27: 430-433

[17] Caggiati A, Franceschini M. Stroke following endovenous laser treatment of varicose veins. J Vasc Surg 2010; 51: 218-220

[18] Cavezzi A, Parsi K. Complications of foam sclerotherapy. Phlebology 2012; 27(Suppl 1): 46-51

[19] Cavezzi A, Tessari L. Foam sclerotherapy techniques: different gases and methods of preparation, catheter versus direct injection. Phlebology 2009; 24: 247-251

[20] Cavezzi A, Frullini A, Ricci S et al. Treatment of varicose veins by foam sclerotherapy: two clinical series. Phlebology 2002; 17: 13-18

[21] Ceulen RPM, Bullens-Goessens YIJM, Pi-Van De Venne SJA. Outcomes and side effects of duplex-guided sclerotherapy in the treatment of great saphenous veins with $1 \%$ versus $3 \%$ Polidocanol foam: results of a randomized controlled trial with 1-year follow-up. Dermatol Surg 2007; 33: 276-28

[22] Ceulen RPM, Jagtmann EA, Sommer A et al. Blocking the saphenafemoral junction during ultrasound guided foam sclerotherapy - assessment of a presumed safety-measure procedure. Eur J Vasc Endovasc Surg 2010; 40: 772-776

[23] Chapman-Smith P, Browne A. Prospective five year study of ultrasound guided foam sclerotherapy in the treatment of great saphenous vein reflux. Phlebology 2009; 24: 183-188

[24] Chen C-H, Chiu C-S, Yang C-H. Ultrasound-guided foam sclerotherapy for treating incompetent great saphenous veins results of 5 years of analysis and morphologic evolvement study. Dermatol Surg 2012; 38: 851-857

[25] Coleridge Smith P. Chronic venous disease treated by ultrasound guided foam sclerotherapy. Eur J Vasc Endovasc Surg 2006; 32 577-583

[26] Coleridge Smith P. Sclerotherapy and foam sclerotherapy for varicose veins. Phlebology 2009; 24: 260-269

[27] Coleridge-Smith P, Labropoulos N, Partsch H et al. Duplex ultrasound investigation of the veins in chronic venous disease of the lower limbs - UIP consensus document. Part I. Basic principles. Eur J Vasc Endovasc Surg 2006; 31: 83-92

[28] Darvall KA, Bate GR, Adam D] et al. Duplex ultrasound outcomes following ultrasound guided foam sclerotherapy of symptomatic recurrent great saphenous varicose veins. Eur ] Vasc Endovasc Surg 2011; 42: 107-114

[29] Darvall KAL, Sam RC, Bate GR et al. Photoplethysmographic Venous Refilling Times Following Ultrasound Guided Foam Sclerotherapy for Symptomatic Superficial Venous Reflux: Relationship with Clinical Outcomes. Eur J Vasc Endovasc Surg (2010) 40, 267-272

[30] De Laney MC, Bowe CT, Higgins GLIII. Acute stroke from air embolism after leg Sclerotherapy. West J Emerg Med 2010; 11: 397

[31] De Maeseneer M, Pichot O, Cavezzi A et al. Duplex ultrasound investigation of the veins of the lower limbs after treatment for varicose veins - UIP consensus document. Eur J Vasc Endovasc Surg 2011; 42: 89-102

[32] De Roos KP, Groen L, Leenders AC. Foam sclerotherapy: investigating the need for sterile air. Dermatol Surg 2011; 37: 1119-1124

[33] De Waard MM, Der Kinderen DJ. Duplex ultrasonography - guided foam sclerotherapy of incompetent perforator veins in a patient with bilateral venous leg ulcers. Dermatol Surg 2005; 31: 580-583

[34] Deichman B, Blum G. Cerebrovascular accident after sclerotherapy. Phlebologie 1995; 24: 148-152

[35] DL50 Sotradecol literature. (bioniche pharma group). 
[36] Drake LA, Dinehart SM, Goltz RW et al. Guidelines of care for sclerotherapy treatment of varicose and teleangiectatic leg veins. J Am Acad Dermatol 1996; 34: 523-528

[37] Fabi SG, Peterson JD, Goldman MP et al. An investigation of coagulation cascade activation and induction of fibrinolysis using foam sclerotherapy of reticular veins. Dermatol Surg 2012; 38: 367-372

[38] Feied CF, Jackson J], Bren TS et al. Allergic reactions to polidocanol for vein sclerosis. J Dermatol Surg Oncol 1994; 20: 466-468

[39] Ferrara E, Bernbach HR. Efficacite de la sclerotherapie a la mousse en fonction de l'aiguille utilisee. Phlébologie Ann Vasc 2005; 58 : 229-234

[40] Ferrara F, Bernbach HR. La compression échoguide é aprés sclérothérapie. Phlébologie 2009; 62: 36-41

[41] Forlee MV, Grouden M, Moore DJ et al. Stroke after varicose vein foam injection sclerotherapy. J Vasc Surg 2006; 43: 162-164

[42] forms of varicose disease of pelvic veins. Vestn Khir Im II Grek 2008; 167: 43-45

[43] Franco G. Explorations ultrasonographiques des re 'cidives variqueuses post-chirurgicales. Phle' bologie 1998; 51: 403-413

[44] Frullini A, Barsotti MC, Santoni T et al. Significant endothelin release in patients treated with foam sclerotherapy. Dermatol Surg 2012; 38 : 741-747

[45] Frullini A, Felice F, Burchielli $S$ et al. High production of endothelin after foam sclerotherapy: a new pathogenetic hypothesis for neurological and visual disturbances after sclerotherapy. Phlebology 2011; 26: $203-208$

[46] Gachet G, Spini L. Sclerotherapie des varices sous anticoagulants. Phlebologie 2002; 55: 41-44

[47] Georgiev M]. Postsclerotherapy hyperpigmentations: a one-year follow-up. Dermatol Surg Oncol 1990; 16: 608-610

[48] Geukens J, Rabe E, Bieber T. Embolia cutis medicamentosa of the foot after sclerotherapy. Eur J Dermatol 1999; 9: 132-133

[49] Gillet JL, Donnet A, Lausecker M et al. Pathophysiology of visual disturbances occurring after foam sclerotherapy. Phlebology 2010; 25: $261-266$

[50] Gillet JL, Guedes JM, Guex JJ et al. Phlebology 2009; 24: 86

[51] Gillet JL, Guedes JM, Guex JJ et al. Side effects and complications of foam sclerotherapy of the great and small saphenous veins: a controlled multicentre prospective study including 1025 patients. Phlebology 2009; 24: 131-138

[52] Gillet JL. Neurological complications of foam sclerotherapy: fears and reality. Phlebology 2011; 26: 277-279

[53] Gohel MS, Epstein DM, Davies AH. Cost-effectiveness of traditional and endovenous treatments for varicose veins. Br J Surg 2010; 97: 1815-1823

[54] Goldman MP, Sadick NS, Weiss RA. Cutaneous necrosis, telangiectatic matting and hyperpigmentation following sclerotherapy. Dermatol Surg 1995; 21: 19-29

[55] Goldman PM, Beaudoing D, Marley W et al. Compression in the Treatment of Leg Telangiectasia: A Preliminary Report. Dermatol Surg 1990; (16)4:322-325

[56] Grommes J, Franzen EL, Binnebösel M et al. Inadvertent arterial injection using catheter-assisted sclerotherapy resulting in amputation. Dermatol Surg. 2011; 42(9): 723-724

[57] Grondin L, Young R, Wouters L. Scle'rothe'rapie echo-guidee et securite: Comparaison des techniques. Phlebologie 1997; 50: 241-245

[58] Guex J], Allaert F-A, Gillet J-L. Immediate and midterm complications of sclerotherapy: report of a prospective multicenter registry of 12,173 sclerotherapy sessions. Dermatol Surg 2005; 31: 123-128

[59] Guex J], Hamel-Desnos C, Gillet JL et al. Sclerotherapie des varices par mousse echoguidee: techniques de mise en oeuvre, indications, resultats publies. Phlebologie 2008; 61: 261-270
[60] Guex J]. Complications of sclerotherapy: an update. Dermatol Surg 2010; 36: 1056-1063

[61] Guex JJ. Les contre-indications de la sclerotherapie, mise a` jour 2005.J Mal Vasc 2005; 30: 144-149

[62] Guex JJ. Thombotic complications of the varicose disease. J Dermatol Surg 1996; 22: 378-382

[63] Guex J]. Ultrasound guided sclerotherapy (USGS) for perforating veins. Hawaii Med J 2000; 59: 261-262

[64] Guyatt G, Gutterman D, Baumann MH et al. Grading strength of recommendations and quality of evidence in clinical guidelines: report from an American College of Chest Physicians Task Force. Chest 2006; 129: $174-181$

[65] Uncu H. Sclerotherapy: a study comparing polidocanol in foam and liquid form Phlebology 2010; 25: 44-49

[66] Hahn M, Schulz T, Jünger M. Sonographically guided, transcatheter foam sclerotherapy of the great saphenous vein. Medical and economic aspects. Phlebologie 2007; 36: 309-312

[67] Hahn M, Shulz T, Juenger M. Late stroke after foam sclerotherapy. VASA 2010; 39: 108-110

[68] Hamel-Desnos C, Desnos P, Ferre B et al. In vivo biological effects of foam sclerotherapy. Eur J Vasc Endovasc Surg 2011; 42: 238-245

[69] Hamel-Desnos C, Desnos P, Wollmann JC et al. Evaluation of the efficacy of polidocanol in the form of foam compared with liquid form in sclerotherapy of the long saphenous vein: Initial results. Dermatol Surg 2003; 29: 1170-1175

[70] Hamel-Desnos C, Guias B], Desnos PR et al. Foam sclerotherapy of the saphenous veins. Randomised controlled trial with or without compression. Eur J Vasc Endovasc Surg 2010; 39: 500-507

[71] Hamel-Desnos C, Ouvry P, Benigni JP et al. Comparison of $1 \%$ and $3 \%$ polidocanol foam in ultrasound guided sclerotherapy of the great saphenous vein: a randomised, double-blind trial with 2 year-followup. 'The 3/1 Study'. Eur J Vasc Endovasc Surg 2007; 34: 723-729

[72] Hamel-Desnos C, Ouvry P, Desnos P et al. Sclerotherapie et thrombophilie: Demarche pour un consensus dans la sclerotherapie chez les thrombophiles. Phlebologie 2003; 56: 165-169

[73] Hamel-Desnos CM, Gillet J-L, Desnos PR et al. Sclerotherapy of varicose veins in patients with documented thrombophilia: a prospective controlled randomized study of 105 cases. Phlebology 2009; 24: 176-182

[74] Hanisch F, Müller T, Krivocuca M et al. Stroke following variceal sclerotherapy. Eur J Med Res 2004; 9: 282-284

[75] Harzheim M, Becher $\mathrm{H}$. Klockgether: Brain infarct from a paradoxical embolism following a varices operation. Dtsch Med Wochenschr 2000; 125: 794-796

[76] Hertzman PA, Owens R. Rapid healing of chronic venous ulcers following ultrasound-guided foam sclerotherapy. Phlebology 2007 22: 34-39

[77] Hesse1 G, Breu FX, Kuschmann A et al. Sclerotherapy using air- or CO2-O2-foam: post- approval study. Phlebologie 2012; 41: 77-88.

[78] Peterson JD, Goldman MP. Phlebology 2012; 27: 73-76

[79] Jia X, Mowatt G, Burr JM et al. Systematic review of foam sclerotherapy for varicose veins. Br J Surg 2007; 94: 925-936

[80] Jiang P, van Rij AM, Christie R et al. Recurrent varicose veins: patterns of reflux and clinical severity. Cardiovasc Surg 1999; 7: 332-339

[81] Kahle B, Leng K. Efficacy of sclerotherapy in varicose veins - a prospective, blinded placebocontrolled study. Dermatol Surg 2004; 30: $723-728$

[82] Kakkos SK, Bountouroglou DG, Azzam M et al. Effectiveness and safety of ultrasound-guided foam sclerotherapy for recurrent varicose veins: immediate results. Journal of Endovascular Therapy 2006; 13: 357-364 
[83] Kanter A, Thibault P. Saphenofemoral junction incompetence treated by ultrasound-guided sclerotherapy. Dermatol Surg 1996; 22: 648-652

[84] Kas A, Begue M, Nifle C et al. Infarctus cerebelleux apres sclerotherapie de varicosite's des membres inferieurs. Presse Med 2000; 29: 1935

[85] Kern P, Ramelet AA, Wütschert R et al. Compression after sclerotherapy for elangiectasiastelangiectasias and reticular leg veins. A randomized controlled study. J Vasc Surg 2007; 45: 1212-1216

[86] Kern P, Ramelet A-A, Wutschert R et al. Single blind randomized study comparing chromated glycerin, polidocanol solution and polidocanol foam for treatment of telangiectactic leg veins. Dermatol Surg 2004; 30: $367-372$

[87] Kölbel T, Hinchliffe RJ, Lindbal B. Catheter-directed foam sclerotherapy of axial saphenous reflux. Early results. Phlebology 2007; 22: 219-22

[88] Kreussler: Fachinformationen Aethoxysklerol 0,25\%/0,5\%/1\%/2\%/3\% Stand Oktober 2009, Chemische Fabrik Kreussler \& Co GmbH

[89] Künzelberger B, Pieck C, Altmeyer $P$ et al. Migraine ophthalmique with reversible scotomas after sclerotherapy with liquid $1 \%$ polidocanol. Derm Surg 2006; 32: 1410

[90] Lee BB, Do YS, Byun HS et al. Advanced management of venous malformation with ethanol sclerotherapy: mid-term results. J Vasc Surg 2003; 37: 533-538

[91] Leslie-Mazwi TM, Avery LL, Sims JR. Intra-arterial air thrombogenesis after cerebral air embolism complicating lower extremity sclerotherapy. Neurocrit Care 2009; 11: 97-100

[92] Ma RWL, Pilotelle A, Paraskevas P et al. Three cases of stroke following peripheral venous interventions. Phlebology 2011; 26: 280-284

[93] Masuda EM, Kessler DM, Lurie F et al. The effect of ultrasound guided sclerotherapy of incompetent perforator veins on venous clinical severity scores. J Vasc Surg 2006; 43: 551-556.

[94] Mc Donagh B, Sorenson S, Gray C et al. Clinical spectrum of recurrent postoperative varicose veins and efficacy of sclerotherapy management using the compass technique. Phlebology 2003; 18: 173-186

[95] Mercer KG, Scott D], Berridge DC. Preoperative duplex imaging is required before all operations for primary varicose veins. Br J Surg 1998; 85: 1495-1497

[96] Morrison N, Cavezzi A, Bergan J et al. Regarding 'stroke after varicose vein foam injectionsclerotherapy. J Vasc Surg. 2006 Jul;44(1): 224-225

[97] Morrison N, Neuhardt DL, Rogers CR et al. Comparisons of side effects using air and carbon dioxide foam for endovenous chemical ablation. J Vasc Surg 2008; 47: 830-836

[98] Morrison N, Neuhardt DL, Rogers CR et al. Incidence of side effects using carbon dioxide oxygen foam for chemical ablation of superficial veins of the lower extremity. Eur J Vasc Endovasc Surg 2010; 40: 407-413

[99] Munavalli GS, Weiss RA. Complications of sclerotherapy. Semin Cutan Med Surg 2007; 26: 22-28

[100] Myers KA, Jolley D. Factors affecting the risk of deep venous occlusion after ultrasound-guided sclerotherapy for varicose vein. Eur J Vasc Endovasc Surg 2008; 36: 602-605

[101] Myers KA, Jolley D, Clough A et al. Outcome of Ultrasound-guided Sclerotherapy for Varicose Veins: Medium-term Results Assessed by Ultrasound Surveillance. Eur J Vasc Endovasc Surg 2007; 33: 116-121

[102] Morrison, Neuhardt DL. Foam sclerotherapy: cardiac and cerebral monitoring Phlebology 2009; 24: 252-259

[103] Nootheti PK, Cadag KM, Magpantay A et al. Efficacy of graduated compression stockings for an additional 3 weeks after sclerotherapy treatment of reticular and telangiectatic leg veins. Dermatol Surg 2009; 35: 53-58
[104] Norris M], Carlin MC, Ratz JL. Treatment of essential telangiectasias: Effects of increasing concentrations of polidocanol. J Am Acad of Dermatol 1989; 20: 643-649

[105] Oesch A, Stirnemann P, Mahler F. The acute ischemic syndrome of the foot after sclerotherapy of varicose veins. Schweiz Med Wochenschr 1984; 114: 1155-1158

[106] Vega F, Ramírez C, Cázarez H et al. 1st Mexican Sclerotherapy Consensus. Phlebologie 2014; 43(01): 37-41

[107] Ouvry P, Allaert FA, Desnos P et al. Efficacy of polidocanol foam versus liquid in sclerotherapy of the great saphenous vein: a multicenter randomized controlled trial with a 2-year follow-up. Eur J Vasc Surg 2008; 36: 366-370

[108] Pang KH, Bate GR, Darvall KAL et al. Healing and Recurrence Rates Following Ultrasound-guided Foam Sclerotherapy of Superficial Venous Reflux in Patients with Chronic Venous Ulceration. Eur vasc Jour. 2010; 40:6, 790-795

[109] Paraskevas P. Successful ultrasound-guided foam sclerotherapy for vulval and leg varicosities secondary to ovarian Vein reflux: a case study. Phlebology 2011; 26: 29-31

[110] Parsi K. Catheter-directed sclerotherapy. Phlebology 2009; 24: 98-107

[111] Parsi K. Paradoxical embolism, stroke and sclerotherapy. Phlebology 2012; 27: 147-167

[112] Parsi K. Venous gas embolism during foam sclerotherapy of saphenous veins despite recommended treatment modifications. Phlebology $2011 ; 26: 140-147$

[113] Passariello F. Sclerosing foam and patent foramen ovale. The final report. In: Word Congress of the International Union of Phlebology; 2007 Jun 18-20; Kyoto, Japan. Int Angiol 2007; 26: 87

[114] Peterson JD, Goldman MP, Weiss RA, et al. Treatment of reticular and telangiectatic leg veins: double-blind, prospective comparative trial of polidocanol and hypertonic saline. Dermatol Surg 2012; 38: 1-9

[115] Picard C, Deltombe B, Duru C et al. Foam sclerotherapy: a possible cause of ischaemic stroke? J Neurol Neurosurg Psychiatry. 2010 May;81(5):582-3

[116] Polidocanol microfoam compared with surgery or sclerotherapy in the management of varicose veins in the presence of trunk vein incompetence: European randomized controlled trial. Phlebology 2006; 21: 180-190

[117] Pradalier A, Vincent D, Hentschel V et al. Allergie aux sclerosants des varices. Rev Fr Allergol 1995; 35: 440-3. 121.preliminary report. J Dermatol Surg Oncol 1990; 16: 322-325

[118] Rabe E, Otto J, Schliephake D et al. Efficacy and Safety of Great Saphenous Vein Sclerotherapy Using Standardised Polidocanol Foam (ESAF): a randomized controlled multicentre clinical trial. Eur J Endovasc Vasc Surg 2008; 35: 238-245

[119] Rabe E, Pannier F, Gerlach $\mathrm{H}$ et al. Leitlinie Sklerosierungsbehandlung der Varikose. Phlebologie 2008; 37: 27-34

[120] Rabe E, Pannier-Fischer F, Gerlach $\mathrm{H}$ et al. Guidelines for sclerotherapy of varicose veins. Dermatol Surg 2004; 30: 687-693

[121] Rabe E, Schliephake D, Otto J et al. Sclerotherapy of telangiectasias and reticular veins: a double-blind, randomized, comparative clinical trial of polidocanol, sodium tetradecyl sulphate and isotonic saline (EASI study). Phlebology 2010; 25: 124-131

[122] Ramelet AA, Parmentier L. Delayed Nicolau's Livedoid dermatitis after ultrasound-guided sclerotherapy. Dermatol Surg 2010; 36: 155-158

[123] Ramelet AA. Phlebologie esthetique. Telangiectasies: possibilites therapeutiques. Cosme 'tologie et Dermatologie esthetique. Paris: Elsevier Masson SAS 2010

[124] Rao J, Wildemore JK, Goldmann MP. Double-blind prospective comparative trial between foamed and liquid 12 Phlebology $0(0)$ polidocanol and natrium tetradecyl sulfate in the treatment of varicose and telangiectatic leg veins. Dermatol Surg 2005; 31: 631-635 
[125] Rasmussen LH et al. Randomized clinical trial comparing endovenous laser ablation, radiofrequency ablation, foam sclerotherapy and surgical stripping for great saphenous varicose veins. Br J Surg 2011; 98: 1079-1087

[126] Rathbun S, Norris A, Stoner J. Efficacy and safety of endovenous foam sclerotherapy: meta-analysis for treatment of venous disorders. Phlebology 2012; 27: 105-117

[127] Rautio T, Perala J, Biancari F et al. Accuracy of handheld Doppler in planning the operation for primary varicose veins. Eur J Vasc Endovasc Surg 2002; 24: 450-455

[128] Reich-Schupke S, Weyer K, Altmeyer P et al. Treatment of varicose tributaries with sclerotherapy with polidocanol $0.5 \%$ foam. Vasa 2010; 39: 169-174

[129] Rathbun S, Norris† A, Stoner† J. Phlebology 2012; 27: 105-117

[130] Sadoun S, Benigni JP, Sica M. Etude prospective de l’efficacite de la mousse de sclerosant dans le traitement des varices tronculaires des membres inferieurs. Phlebologie 2002; 55: 259-262

[131] Sarvananthan T, Shepherd AC, Willenberg T et al. Neurological complications of sclerotherapy for varicose veins. J Vasc Surg 2012; 55: 243-251

[132] Schadeck M, Allaert FA. Resultats a long terme de la Sclerotherapie des Saphenes internes. Phlebologie 1997; 50: 257-262

[133] Schuller-Petrovic S, Brunner F, Neuhold N et al. Subcutaneous injection of liquid and foamed polidocanol: extravasation is not responsible for skin necrosis during reticular and spider vein sclerotherapy. JEADV 2011; 25: 983-986

[134] Schultz-Ehrenburg U, Tourbier H. Doppler-kontrollierte Verödungsbehandlung der Vena saphena magna.Phlebol u Proktol 1984; 13: $117-22$

[135] Sclerotherapy resulting in amputation. Dermatol Surg 2010; 37 : 536-538

[136] Sclerotherapy'. J Vasc Surg 2006; 44: 224-5

[137] Scultetus AH, Villavicencio JL, Kao TC, et al. Microthrombectomy reduces postsclerotherapy pigmentation: multicenter randomized trial. J Vasc Surg 2003; 38: 896-903

[138] Shadid N, Ceulen R, Nelemans P et al. Randomized clinical trial of ultrasound-guided foam sclerotherapy versus surgery for the incompetent great saphenous vein. Br J Surg 2012; 99: 1062-1070

[139] Stanley PRW, Bickerton DR, Campbell WB. Injection sclerotherapy for varicose veins - a comparison of materials for applying local compression. Phlebology 1991; 6: 37-39

[140] STD Pharmaceutical Products Ltd. Prescribing Information, March 2012

[141] Stücker M, Reich S, Hermes N et al. Safety and efficiency of perilesional sclerotherapy in leg ulcer patients with postthrombotic syndrome and/or oral anticoagulation with Phenprocoumon. JDDG 2006; 4: 734-738

[142] Sukovatykh BS, Rodionov OA, Sukovatykh MB et al. Diagnosis and treatment of atypical forms of varicose disease of pelvic veins. Vestn Khir Im I I Grek. 2008;167(3):43-45

[143] Kölbel T et al. Catheter-directed foam Phlebology Vol 22 No. 52007

[144] Tessari L, Cavezzi A, Frullini A. Preliminary experience with a new sclerosing foam in the treatment of varicose veins. Dermatol Surg 2001; 27: 58-60

[145] Tessari L, Cavezzi A, Rosso M et al. Variables in foam sclerotherapy: literature and experimental data. ANZJ Phleb 2008; 11: 83-84

[146] Times following ultrasound guided foam sclerotherapy for symptomatic superficial venous reflux: relationship with clinical outcomes. EJVES 2010; 40: 267-272

[147] Tratado de Flebologia y Linfología Edgardo Attman Canestrio, Cesar federico sanchez, Ursula Tropper. Fundacion flebológica Ar.gentina|997
[148] Ultrasound guided foam sclerotherapy of superficial venous reflux in patients with chronic venous ulceration. Eur J Vasc endovasc Surg 2010; 40: 790-795

[149] Uncu H. Sclerotherapy: a study comparing polidocanol in foam and liquid form. Phlebology 2010; 25: 44-49

[150] Van der Plas JPL, Lambers JC, van Wersch JW et al. Reversible ischaemic neurological deficit after sclerotherapy of varicose veins. Lancet 1994; 343: 428

[151] Van Neer P, Veraart JCJM, Neumann H. Posterolateral thigh perforator varicosities in 12 patients: a normal deep venous system and successful treatment with ultrasound-guided sclerotherapy. Dermatol Surg 2006; 32: 1346-1352

[152] Vega et al. México Sclerotherapy II. Phlebolymphology:Vol.20. No.1.2012.pp 43-44 Versicherungsmedizin 2000; 4: 185-187

[153] Vin F. Principes de la Sclerotherapie des Troncs Saphe `nes Internes. Phlebologie 1997; 50: 229-234

[154] Wagdi P. Migrane und offenes Foramen Ovale: nur ein vorübergehender Hoffnungsschimmer? Kardiovasc Med 2006; 9: 32-36

[155] Weiss RA and Weiss MA. Incidence of side effects in the treatment of telangiectasiastelangiectasias by compression sclerotherapy: hypertonics saline vs. polidocanol. J Dermatol Surg Oncol 1990; 16: 800-804

[156] Weiss RA, Sadick NS, Goldman MP et al. Post-sclerotherapy compression: controlled comparative study of duration of compression and its effects on clinical outcome. Dermatol Surg 1999; 25: 105-108

[157] Wildenhues B. Catheter-assisted foam sclerotherapy: a new minimally invasive method for the treatment of trunk varicosis of the long and short saphenous veins. Phlebologie 2005; 34: 165-170

[158] Wollmann JC. The history of sclerosing foams. Dermatol Surg 2004; 30: 694-703

[159] Wright D, Gobin JP, Bradbury AW et al. Varisolve European Phase III Investigators Group. Varisolve_

[160] Yamaki T, Hamahata A, Soejima K et al. Prospective randomised comparative study of visual foam sclerotherapy alone or in combination with ultrasound-guided foam sclerotherapy for treatment of superficial venous insufficiency: preliminary report. EJVES 2012; 43: 343-347

[161] Ymaki T, Nozaki M, Iwasaka S. Comparative study of duplex-guided foam sclerotherapy and duplex-guided liquid sclerotherapy for the treatment of superficial venous insufficiency. Dermatol Surg 2004; 30(5): 718-722

[162] Yamaki T, Nozaki M, Sakurai $\mathrm{H}$ et al. Multiple smalldose injections can reduce the passage of sclerosant foam into deep veins during foam sclerotherapy for varicose veins. Eur J Endovasc Surg 2008; 37: 343-8

[163] Yamaki T, Nozaki M, Sakurai H et al. Prospective randomized efficacy of ultrasound-guided foam sclerotherapy compared with ultrasound-guided liquid sclerotherapy in the treatment of symptomatic venous malformations. J Vasc Surg 2008; 47: 578-84

[164] Yamaki T, Nozaki Mand Sasaki K. Color duplex-guided sclerotherapy for the treatment of venous malformations. Dermatol Surg 2000; 26 : 323-328

[165] Zarca C, Bailly C, Gachet G et al. ClassMousse 1 study: compression hosiery and foam sclerotherapy. Phlebologie 2012; 65: 11-20

[166] Zhang J, Jing Z, Schliephake DE et al. Efficacy and safety of Aethoxysklerol (polidocanol) $0.5 \%, 1 \%$ and $3 \%$ in comparison with placebo solution for the treatment of varicose veins of the lower extremities in Chinese patients (ESA-China Study). Phlebology 2012; 27: 184-90

[167] Brian C. Leach MD, Mitchel P. Goldman MD. Comparative Trial Between Sodium Tetradecyl Sulfate and Glycerin in the Treatment of Telangiectatic Leg Veins. Dermatologyc Surgery 2003; 29 (6): 612-615

[168] Margare A. Weiss, Jeffrey T. S. Hsu, Isaac Neuhaus et al. Consensus for Sclerotherapy. Dermatologic Surgery 2014; 4 0: 12: 1309-1318 
[169] Morales-Hernández AE, Valencia-López R, Hernández-Salcedo DR et al. Síndrome de Takotsubo. Med Int Méx 2016; 32(4): 475-491

[170] Laura Fortuna, Eduardo Moreyra, Lilian Hamity et al. Síndrome de Takotsubo experiencia en tres instituciones de la ciudad de córdoba. Medicina (buenos aires) 2014; 74: 42-48
[171] Fernando Vega Rasgado. The need for a consensus on venous ultrasound-guided sclerotherapy. Phlebolympho. 2014; 21,pp.25

[172] Vega F, Pastrana V, et al. Foam prepared with pure oxygen decrease adverse effects in sclerotherapy. Int Angiol. 2018, 37; Sup 1, pp6 